\title{
Introduction: The Snow of Yesteryear
}

\author{
GER A L D WEISS M A N \\ NYU School of Medicine, 550 First Ave New York, NY 10024, USA. \\ Email: gerald.weissmann@med.nyu.edu
}

This Focus presents a bouquet of personal essays written in response to re-reading C.P. Snow's historic formulation of 'The Two Cultures and the Scientific Revolution'. Each of the authors, in person and in writing, stands in the vanguard of contemporary science and/or the liberal arts. Their essays, based on Snow's description of a cultural gap between scientists and the 'literary intellectuals', will explore the state of the two cultures today and probe whether the digital age has put our humanist heritage at risk. Six decades after Snow's presentation, we'll ask if the cultural split he defined remains pertinent in the age of Twitter - and if our common culture faces greater threats today.

Without Art, we should have no notion of the sacred; without Science, we should always worship false gods. (W.H. Auden ${ }^{1}$ )

On 7 May 1959, Sir Charles Percy Snow presented the Rede lecture to a gowned audience in the Senate House of Cambridge University. He titled his lecture 'The Two Cultures' to describe differences in mind-set between the humanities and science, and the deep rift separating the two. In his lecture, Snow recalled:

A good many times I have been present at gatherings of people who, by the standards of the traditional culture, are thought highly educated and ... have asked the company how many of them could describe the Second Law of Thermodynamics. The response was cold: it was also negative. Yet I was asking something which is about the scientific equivalent of: 'Have you read a work of Shakespeare's?'

A year later, in the printed version of his lecture, Snow added 'The Scientific Revolution' to the title, coining that term to describe a new 'industrial society of electronics, atomic energy, automation.'

C.P. Snow (1905-1980) knew well the two cultures of which he spoke. After postdoctoral research in spectroscopy, ${ }^{3,4}$ Snow was elected a Fellow of Christ's College, Cambridge in 1930. In the course of his later career at the highest level of government service, he received a CBE in 1943 and was knighted by Queen Elizabeth II in 1957. Snow was also a celebrated novelist whose works at the time included The Affair, 
which addressed science fraud, and The Masters, which featured academic high-jinks at an unnamed Cambridge college. ${ }^{5}$

Snow told his Senate House audience that, in the course of his broad war and postwar experience with scientific personnel, he and his colleagues had asked thousands of young scientists about their reading habits: at best they might own that 'well I've tried a bit of Dickens'. Snow worried that, at least in Britain, the traditional culture still reigned: entropy placed second to Oliver Twist. Snow pleaded that the polarization between these two cultures was 'a sheer loss to us all'. He flew the flag for physical science, claiming that the scientists had 'the future in their bones', while the literary intellectuals of his day could be dismissed as natural Luddites who wished 'the future did not exist'.

Snow accused literary lions, such as W.B. Yeats, Wyndham Lewis and Ezra Pound, of supporting politics 'that led to Auschwitz'. He saw it coming: in 2017, a resurgent Fascist party in Italy has called itself Casa Pound - to honour the American poet who broadcast racist doctrine from Rome during the Second World War.

Snow also warned that post-war Britain was not producing a sufficient number of trained scientists or engineers to compete in the modern world, reviving a perennial debate between backers of applied science and the humanities. The contest has expanded from the Industrial to the Digital Revolution, and a recent episode involved two giants of Silicon Valley. Bill Gates of Microsoft fame warned a National Governors' conference in 2011 that the US was seriously behind other countries in promoting STEM (science, technology, engineering and math) degrees, which were 'well correlated to areas that actually produce jobs'. That same year, Steve Jobs rolled out Apple's newest iPad - and a minor slip in molecular genetics - claiming that 'It's in Apple's DNA that technology alone is not enough. It's technology married with liberal arts, married with the humanities, that yields us the result that makes our heart sing. ${ }^{6}$

In the six decades since 'Two Cultures and The Scientific Revolution' appeared, we have experienced not only the digital and genomic revolutions in science, but also a brisk counter-revolution of Science Deniers. If the widespread use of machines in the nineteenth century created a violent Luddite reaction, so the widespread use of social media in the twenty-first century has enabled both polymaths and monomaniacs. Twitter is ablaze with Tweets from the White House that warn our citizens that climate change is a hoax, that light bulbs cause cancer and that autism results from vaccines. ${ }^{7}$ Notions such as these are more troubling than ignorance of the Second Law of Thermodynamics and do not come from literary intellectuals or scholars in the humanities. They challenge us to keep the future in our bones and humanities in our head.

Therefore we've come together to revisit, and honour, the Two Cultures of which Snow spoke. Each of the authors, in person and in writing, stands at the vanguard of contemporary science and/or the liberal arts. Their essays, based on Snow's description of a cultural gap between scientists and the 'literary intellectuals', will explore the state of the two cultures and ask whether the digital age has put our humanist heritage at risk. The texts of that legacy - from Aeschylus to Tolstoy to Orwell - have been 
called 'The Great Conversation' by Chancellor Robert Hutchins. No surprise, then, that the essays in this volume support Hutchins' conviction that 'The rise of experimental science has not made the Great Conversation irrelevant... Science itself is part of the Great Conversation.'8

\section{References}

1. W.H. Auden (1962) The virgin and the dynamo. In The Dyer's Hand (New York: Random House), p. 62.

2. C.P. Snow (1960) The Two Cultures and the Scientific Revolution (Cambridge, UK: Cambridge University Press).

3. F.P. Bowden, S.D.D. Morris and C.P. Snow (1933) Absorption spectrum of vitamin $\mathrm{A}$ at low temperatures. Nature, 131, pp. 582-583 see subsequent correction.

4. C.P. Snow and E. Eastwood (1935) Sources of error in absorption spectroscopy. Nature., 134, p. 186.

5. A. Whitman (1980) C.P. Snow dies at 74. The New York Times, 2 July, p. A20.

6. J. Derbyshire (2016) Degrees of separation. Financial Times Magazine, 26 February.

7. Editorial (2016) Trump's views on science are shockingly ignorant. Scientific American, 1 November, https://www.scientificamerican.com/article/trumpcomments-on-science-are-shockingly-ignorant/.

8. R.M. Hutchins (1954) Preface to Great Books: Vol 1 The Great Conversation (New York: Simon \& Schuster), p. ix.

\section{About the Author}

Gerald Weissmann is Research Professor of Medicine at the NYU School of Medicine. A physician/scientist, he is best known for the co-discovery and naming of liposomes. He has also pursued studies of inflammation in Cambridge, Paris and Woods Hole; he is a past president of the American College of Rheumatology. He has been editor-in-chief of the FASEB Journal and of Inflammation, and published 11 books of essays on arts and science from The Woods Hole Cantata (1985) to The Fevers of Reason (March, 2018). 